\begin{tabular}{|c} 
Ambiente \& Água - An Interdisciplinary Journal of Applied Science \\
ISSN 1980-993X - doi:10.4136/1980-993X \\
www.ambi-agua.net \\
E-mail: ambi.agua@gmail.com
\end{tabular}

\title{
Effect of land-use pattern on the physicochemical and genotoxic properties of water in a low-order stream in Central Brazil
}

\author{
ARTICLES doi:10.4136/ambi-agua.2486
}

Received: 16 Oct. 2019; Accepted: 20 Apr. 2020

\author{
Elisa Flávia Luiz Cardoso Bailão ${ }^{1}$; Leovigildo Aparecido Costa Santos ${ }^{2} \mathbb{D}$; \\ Sara dos Santos Almeida ${ }^{1}$; Patrícia Lima D’Abadia ${ }^{3}$; Ronny José de Morais ${ }^{4}$; \\ Túlio Natalino de Matos $^{5}{ }^{(D}$; Samantha Salomão Caramori ${ }^{1 *}$ (iD; \\ Cleide Sandra Tavares de Araújo ${ }^{5}{ }^{(D)}$; Carlos de Melo e Silva Neto ${ }^{6}$; \\ Luciane Madureira Almeida 5 (i)
${ }^{1}$ Laboratório de Biotecnologia. Universidade Estadual de Goiás (UEG), BR-153, n 3105, CEP: 75132-903, Anápolis, GO, Brazil. E-mail: elisaflavia@gmail.com, saraalmeida08@gmail.com ${ }^{2}$ Programa de Pós-Graduação de Recursos Naturais do Cerrado. Universidade Estadual de Goiás (UEG), BR-153, n³ 3105, CEP: 75132-903, Anápolis, GO, Brazil. E-mail: eng.leovigildo@ gmail.com
${ }^{3}$ Departamento de Recursos Naturais do Cerrado. Universidade Estadual de Goiás (UEG), BR-153, n 3105, CEP: 75132-903, Anápolis, GO, Brazil. E-mail: patricialima.bio@gmail.com ${ }^{4}$ Laboratório de Biogeografia e Ecologia Aquática. Universidade Estadual de Goiás (UEG), BR-153, n 3105, CEP: 75132-903, Anápolis, GO, Brazil. E-mail: ronnybio@ hotmail.com ${ }^{5}$ Universidade Estadual de Goiás, Câmpus Central, BR-153, nº 3105, CEP: 75132-903, Anápolis, GO, Brazil. E-mail: tulio_matos23@hotmail.com,cstarjb@yahoo.com.br, almeidalm@hotmail.com (IFG), Rua 2, S/N, CEP: 7660-000, Goiás, GO, Brazil. E-mail: carlos.neto@ifg.edu.br
*Corresponding author. E-mail: sscaramori@gmail.com \\ ${ }^{6}$ Coordenação de Agroecologia. Campus Cidade de Goiás. Instituto Federal de Educação, Ciência e Tecnologia
}

\begin{abstract}
Low-order streams located near urban areas usually receive domestic, industrial, and agricultural wastewaters that negatively affect river water quality. Additionally, water pollution is associated with land-use variations around the river, which is characterized by unplanned urbanization, intense agricultural activities, and deforestation. This work correlated land-use patterns with physicochemical quality and genotoxic potential of water at four points (P1 to P4) along the Extrema River, located in an industrial and agricultural area of Central Brazil. Physicochemical analyses indicated that the water collected from the Extrema River is inappropriate for human consumption. Using the Allium cepa model, no evidence of cytotoxicity was observed at any point; in contrast, the genotoxic potential of these water samples was observed. The correlation of these results with land use showed that the water collected at P3 was the most contaminated; this is probably due to the inflow of wastewater from municipal, industrial, and agriculture activities. Different results were observed for P2 and $\mathrm{P} 4$, where land-use analysis attributed the water quality to forest burns. We concluded that differential use of the land changed the characteristics of the associated river water, and A. cepa parameters were more related to land-use characteristics than to physicochemical parameters. This study highlighted the importance of associating land use with the cyto genotoxic potential of water.
\end{abstract}

Keywords: agricultural activities, Allium cepa test, sewage, water quality.

This is an Open Access article distributed under the terms of the Creative Commons Attribution License, which permits unrestricted use, distribution, and reproduction in any medium, provided the original work is properly cited. 


\section{Efeito de padrões de uso do solo nas propriedades físico-químicas e genotóxicas da água em um riacho de baixa ordem no Brasil Central}

\section{RESUMO}

Córregos de baixa ordem localizados perto de áreas urbanas geralmente recebem águas residuais domésticas, industriais e agrícolas que afetam negativamente a qualidade da água do rio. Além disso, a poluição da água está associada à variações do uso da terra ao redor do rio, caracterizada pela urbanização não planejada, atividades agrícolas intensas e desmatamento. $\mathrm{O}$ objetivo deste trabalho foi correlacionar o padrão de uso do solo com a qualidade físico-química e o potencial genotóxico da água em quatro pontos (P1 a P4) ao longo do rio Extrema, localizado em uma área industrial e agrícola do Brasil Central. Análises físico-químicas indicaram que a água coletada no rio Extrema é inadequada para consumo humano. Usando o modelo de Allium cepa, nenhuma evidência de citotoxicidade foi observada em nenhum momento; por outro lado, foi observado o potencial genotóxico dessas amostras de água. A correlação desses resultados com o uso do solo mostrou que a água coletada no P3 foi a mais contaminada; isso é provável devido ao influxo de águas residuais municipais e industriais e de águas residuais das atividades agrícolas. Resultados diferentes foram observados para P2 e P4, onde a análise do uso do solo atribuiu a qualidade da água às queimadas na floresta. Concluímos que diferentes usos do solo alteraram as características da água do rio e que os resultados obtidos pelo teste com A. cepa estavam mais relacionados às características do uso do solo do que aos parâmetros físico-químicos. Este estudo destaca a importância de associar o uso do solo ao potencial citogenotóxico da água.

Palavras-chave: atividades agrícolas, efluentes, qualidade da água, Teste de Allium cepa.

\section{INTRODUCTION}

Surface waters are the most important natural and economic resource for agricultural, industrial, and anthropogenic activities. Water quality plays a pivotal role not only in habitat protection but also in public health and socio-economic development (Xiao et al.,2016). Point sources of anthropogenic activities, such as sewage treatment discharge, and nonpoint sources, such as overland runoff from agricultural areas, can pollute surface water. Pollution from nonpoint sources is more difficult to identify than that from point sources because of complex biotic and abiotic interactions between runoff and the landscape (Sliva and Williams, 2001; Giri and Qiu, 2016). Therefore, variation in land use is a principal factor affecting non-point source pollution (Cheng et al., 2018). Land surface characteristics are generally modified by deforestation, agricultural activities, and urbanization; these activities alter runoff volume and water temperature, cause pollution, increase algal production, and decrease the concentration of dissolved oxygen in water bodies (Ding et al., 2015).

Thus, the majority of water pollution problems are caused by changes in land-use patterns within a given basin, as population and economic activity increase (Lee and Bastemeijer, 1991). Unplanned urbanization, intense agricultural activities, and deforestation are positively correlated with stream pollutants such as carbon, nitrogen, and phosphorous; forests and grasslands, which are less influenced by anthropogenic activities, have negative correlations (Bu et al., 2014; Teixeira et al., 2014; Su et al., 2015; Ullah et al., 2018).

In general, agricultural land use has a strong influence on nutrient parameters in river water such as nitrogen and phosphorus content, fecal coliform bacteria, and trace metal elements (Huang et al., 2013; Cao et al., 2013; Woli et al., 2004; Kang et al., 2010). Fertilizers used in agricultural activities have different chemicals such as nitrogen and phosphorus, which can potentially run off into nearby water sources and damage the nutrient content within the water 
body, affecting its overall quality (Permatasari et al., 2017). Industrial and urban land areas are associated with organic pollution, trace metals, nutrients, and fecal coliform bacteria (Li et al., 2009; Kang et al., 2010; Bu et al., 2014).

Because of the close interconnection with land use, low-order streams-which constitute over $50 \%$ of the total stream length - are highly vulnerable to land-disturbing activities such as deforestation, agriculture, and urbanization (Freeman et al., 2007; Ding et al., 2016). These streams transport water, nutrients, organic materials, and sediments from terrestrial uplands to downstream systems. Therefore, anthropogenic activities in low-order streams can increase nutrient loading and reduce nutrient retention, which can result in the eutrophication and hypoxia of distant downstream ecosystems (Dodds and Oakes, 2008; Ding et al., 2016). Despite their important role in maintaining river health, most low-order streams are not routinely monitored for water quality. Therefore, investigating the impacts of land use on water quality in low order streams is crucial. A possible strategy for identifying the principal sources of pollution is the use of multivariate statistical methods on large matrix data (Khan et al., 2016a, $2016 \mathrm{~b}, 2017)$. This method has been successfully used to identify the anthropogenic and natural sources of pollution in surface water bodies (Khan et al., 2016a). The results will be effective not only for protecting local streams, but also for improving downstream water quality (Ding et al., 2016; Norton and Fisher, 2000; Brion et al., 2011).

In this work, we used multivariable analysis to correlate land-use patterns with the physicochemical quality and genotoxic potential of the Extrema River, a low-order stream located in an industrial and agricultural area of Central Brazil. While most of the previous studies correlated land-use patterns with the physicochemical parameters of water, in the present work we also added the genotoxic potential of water. Genotoxic compounds, both known and unknown, are the components of complex environmental mixtures that can have adverse health effects on humans. Therefore, genotoxicity assays should be included as additional parameters in water-quality monitoring programs (Ohe et al., 2004). For the genotoxic analysis performed in the present study, we chose the Allium cepa test because of its simplicity, relatively low cost, high sensitivity, and good correlation when compared with other test systems (Fedel-Miyasato et al., 2014). There is a correlation of $82 \%$ between the A. cepa test and the carcinogenicity test in rodents, and when compared with the prokaryotic model, $A$. cepa is more sensitive than the Ames test (Rank and Nielsen, 1994). The A. cepa test has been validated by the United Nations Environmental Program (UNEP), the World Health Organization (WHO) and the US Environmental Protection Agency (USEPA) as an excellent genetic model for the detection of genotoxicants and is frequently used in environmental monitoring studies (Leme and Marin-Morales, 2009; Sousa et al., 2017; Düsman et al., 2014; Silva et al., 2018; Bollani et al., 2018).

\section{STUDY AREA}

The study was conducted at four points along the Extrema River, in the city of Anápolis, located in the mesoregion of the Goiano Center of Brazil. The area is between 16 ${ }^{\circ} 5^{\prime} 00^{\prime \prime} \mathrm{S}$ and $16^{\circ} 31^{\prime} 24^{\prime \prime} \mathrm{S}$ latitude and $48^{\circ} 42^{\prime} 31^{\prime \prime} \mathrm{W}$ and $49^{\circ} 14^{\prime} 12^{\prime \prime} \mathrm{W}$ longitude at an approximate altitude of $1017 \mathrm{~m}$. According to the Köppen and Geiger classification, Anápolis presents an Aw tropical climate. The mean annual temperature is $22.2 \pm 3.5^{\circ} \mathrm{C}$ and the mean annual precipitation is $1,441 \pm 238 \mathrm{~mm}$ (Climate-Data, 2020). The Extrema River is part of the Antas River watershed and extends for $22,852 \mathrm{~km}$, comprising the regional planation surface IIA (Ferreira et al., 2014). The study area runs from its source to its mouth, where it encounters the Antas River (Figure 1). The Extrema River experiences an inflow of effluents produced by the Industrial District of Anápolis (DAIA) after treatment at the Anápolis effluent treatment station. These effluents are produced by the chemical, pharmaceutical, automotive, food, and agricultural industries (CODEGO, 2018). According to the Department of Environment of DAIA, the load 
of the raw sewage is approximately $3,750 \mathrm{Kg} \mathrm{BOD/day.}$
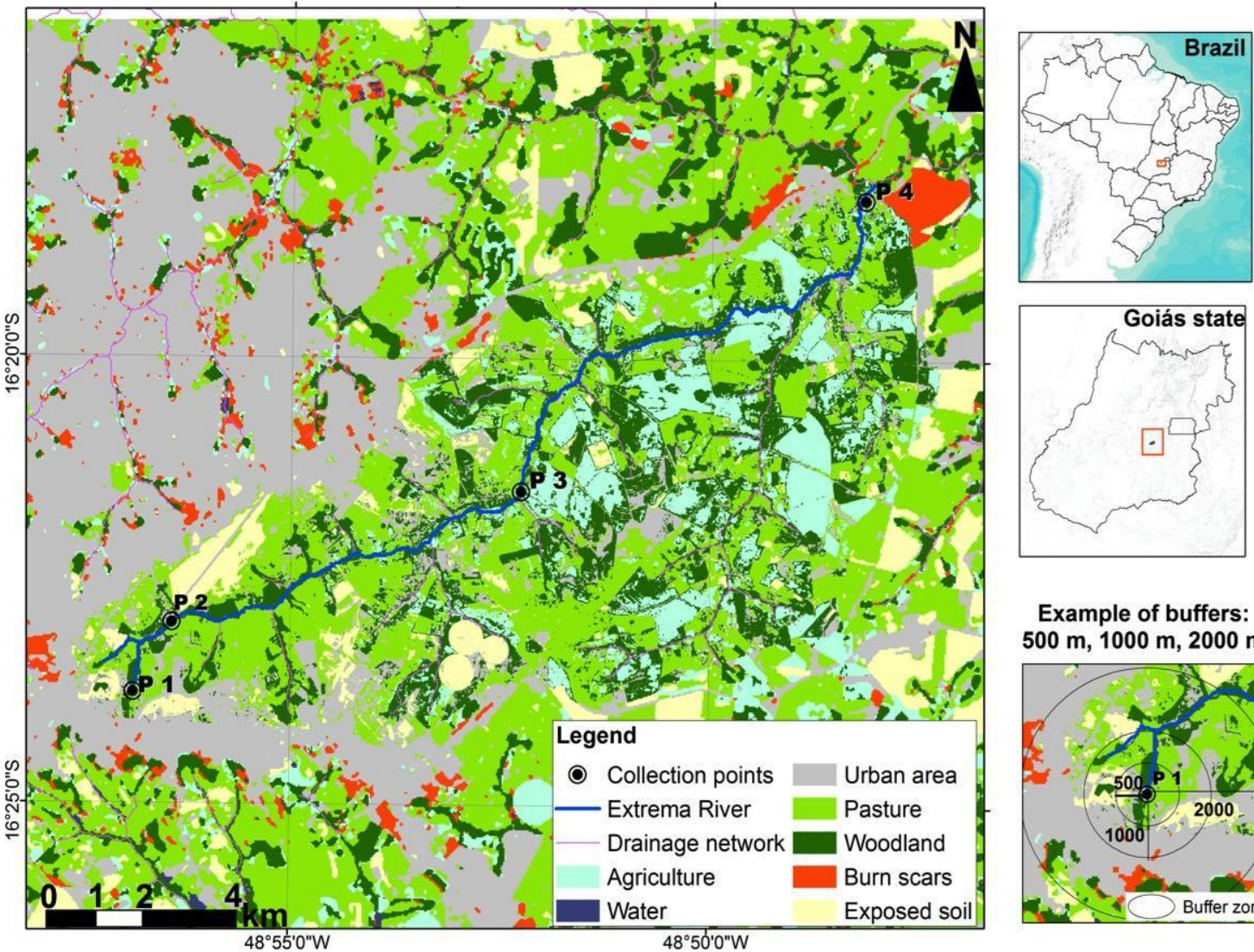

Example of buffers: $500 \mathrm{~m}, 1000 \mathrm{~m}, 2000 \mathrm{~m}$.

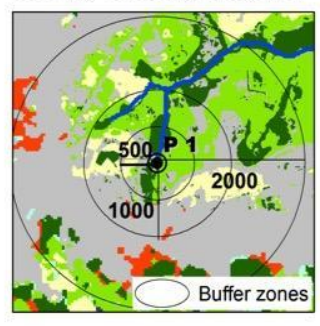

Figure 1. Land-use map showing the locations of the Extrema River and water collection points.

\section{METHODOLOGY}

\subsection{Water sampling and physicochemical analytical methods}

The Extrema River has lentic characteristics and is stratified primarily during the dry season. The low levels of sewer coverage impair the river by increasing the pollutant load, especially during the dry season, and reduce water quality. Consequently, the samples were collected from four locations (P1-P4) along the Extrema River in August 2017, a dry period in the area (Figure 1). Surface water was collected in three different polyethylene bottles $( \pm 500$ $\mathrm{mL}$ ) from each sampling point. The containers were adequately labeled and kept under refrigeration $\left(-4^{\circ} \mathrm{C}\right)$ for further analysis. During sample collection, water temperature $\left({ }^{\circ} \mathrm{C}\right)$, electrical conductivity $(\mu \mathrm{s} / \mathrm{cm})$, dissolved oxygen concentration $\left(\mathrm{mg} / \mathrm{L} \mathrm{O} \mathrm{O}_{2}\right)$, turbidity $(\mathrm{NTU})$, and $\mathrm{pH}$ were obtained using a multiparameter probe (Digimed). Total ammoniacal nitrogen and soluble reactive phosphorus were quantified according to the methods explained by Solórzano (1969) and Murphy and Riley (1962), respectively, in each sample collected from the four points.

An atomic absorption spectrometer (AAnalyst 400, Perkin Elmer, Singapore) equipped with deuterium background correction technology was used to measure the concentration of environmentally hazardous metals through flame atomic absorption spectrometry. A hollowcathode lamp (Perkin Elmer, Singapore) was used as the radiation source. An air/acetylene flame supplied at flow rates of 13.5 and $2.0 \mathrm{~L} / \mathrm{min}$, respectively, was used. First, the water samples were acidified. They were then subjected to acid digestion; the instrument was operated under the conditions recommended by the manufacturer. The $\mathrm{pH}$ of the solutions was adjusted with the addition of $0.3 \mathrm{~mol} / \mathrm{L} \mathrm{NaOH}$ or $\mathrm{HNO}_{3}$ (Merck, Germany) and by using a $\mathrm{pH}$ meter 
equipped with a combined glass electrode. The contents of $\mathrm{Fe}, \mathrm{Zn}, \mathrm{Cu}, \mathrm{Cr}$ and $\mathrm{Pb}$ were analyzed. The metal quantifications were performed by comparing the samples with dilutions of individual analytical grade standard solutions $(1000 \mathrm{mg} / \mathrm{L})$.

\subsection{Toxicity test using Allium cepa assays}

Bulbs of common onion (Allium cepa L.) were purchased from a local supermarket, and 14 bulbs were prepared for each sample. The bulbs were grown in distilled water at room temperature for three days, after which the newly-formed root tips were cut from each bulb and examined morphologically for any visible abnormalities. The bulbs were then treated with surface water collected from the Extrema River. Another set of onion bulbs was placed in distilled water to be a negative control. After $48 \mathrm{~h}$ in the test solutions, seven bulbs were used for macroscopic analysis of toxicity and the root tips of five bulbs were used for microscopic analysis. During macroscopic analysis, each root was measured in centimeters with a ruler. During microscopic analysis, the root tips of each bulb were collected and fixed in a Carnoy's fixative solution (1 acetic acid: 3 alcohol) for $24 \mathrm{~h}$. They were then stored in $70 \%$ alcohol. For analysis, the root tips were rinsed a few times with distilled water and hydrolyzed with $5 \mathrm{M}$ $\mathrm{HCl}$ solution at room temperature for $1 \mathrm{~min}$. Following hydrolysis, the roots were squashed in acetic acid $(45 \%, \mathrm{v} / \mathrm{v})$, and a coverslip was placed on each slide. The coverslips were removed after freezing in liquid nitrogen, and the roots were stained with Giemsa (5\%) for $5 \mathrm{~min}$. The colored slides were evaluated using a Zeiss Optical Microscope (Zeiss, Oberkochen, Germany) with 40x and 100x objectives. In total, 1,000 meristematic cells per slide and 5,000 cells per treatment were analyzed. The cytotoxic potential was calculated through determination of the mitotic index (MI). The MI was calculated for each treatment using the ratio of the number of dividing cells to the total number of cells (Seth et al., 2008). The genotoxic potential was estimated using the number of chromosomal and nuclear aberrations (CNA), and the mutagenic potential was estimated using the number of micronuclei (MN).

\subsection{Spatial analysis of use and land cover}

Landsat-8 Operational Land Imager (OLI) images were chosen for the extraction of information on land use. To match the water quality data, we used the image with path/row number 222/71, which was obtained on September 11, 2017. Further image processing analysis was carried out using ENVI 5.0. According to the methodology described by Santos et al. (2017), we snipped a slit in the area of interest and analyzed the color composition of that area by stacking spectral bands $6(1.560-1.660 \mu \mathrm{m}), 5(0.845-0.885 \mu \mathrm{m})$, and $4(0.630-0.680 \mu \mathrm{m})$. Highlights and contrast were used to facilitate the interpretation of the targets and terrestrial features in the image. For the land-use and ground-cover survey, the supervised maximum likelihood classification method was used-MAXVER (Santos and Lima, 2018). Land use, including that of natural and anthropic areas, was classified into seven types: a) Agriculture, which includes areas occupied by annual and perennial crops; b) Water, which includes lakes, rivers, and streams; c) Urban area, which encompasses roads, residences, and industries; d) Pasture, which comprises pasture areas intended for cattle raising; e) Woodland, which consists of forests with vegetation areas from native Cerrado; f) Burn scar, which includes regions where burnings or forest fires have occurred; and g) Exposed soil, which includes areas without vegetation cover. The overall accuracy of this land-use classification was $96.6 \%$, and the Kappa coefficient was 0.96 , showing high classification accuracy and indicating that the land-use map could be employed in the subsequent analysis. The spatial distribution of land-use and watermonitoring sites in the study area is shown in Figure 1. The proportions of land-use types in the four zones were also computed using ArcGIS 10.2. Buffers of $500 \mathrm{~m}, 1000 \mathrm{~m}$, and $2000 \mathrm{~m}$ radii were created around each water collection point. Geoprocessing tools were used to analyze the total area occupied by each of the land-use types at the different collection sites. The attribute tables containing information on each buffer were exported from ArcGIS in an Excel- 
compatible format and were used in the total and percentage area calculations by mapping class.

\subsection{Statistical analysis}

In the A. серa analysis, the onions were divided for five treatments, each containing five replications. The values obtained from toxicity, genotoxicity, and mutagenic analyses were evaluated through analysis of variance (ANOVA) and compared through Tukey post-hoc tests. The obtained $p<0.05$ value was considered as indicative of significance.

Cell parameters such as root length, MI, CNA, and the incidence of MN were considered response variables for the set of sampled points. Furthermore, all relevant water quality attributes, such as water temperature, electrical conductivity, dissolved oxygen content, turbidity, $\mathrm{pH}$, trace metals, ammoniacal nitrogen, and soluble reactive phosphorus content, were used as environmental parameters. For the characterization of water quality and determination of the interaction between biological parameters, the corresponding canonical analysis (CCA) was applied. The parameters identified for land-use characterization at different distances in the buffers were also analyzed using the same test. Quantitative biological parameters were compared with water- and land-use characteristics using simple polynomial regressions; the statistical significance and regression coefficient were derived.

\section{RESULTS}

\subsection{Physicochemical characteristics of the water collected along Extrema River}

The results of physical analyses (temperature, turbidity, electrical conductivity, dissolved oxygen content, and $\mathrm{pH}$ ) of the samples collected from the Extrema River (P1-P4) were compared with the standards established by the Brazilian law for Class 2 water resources (Table 1), which includes water for human consumption, agriculture, recreation, and fishing activities (CONAMA, 2005).

The samples from P1, P2, and P4 showed results that were within the standards established by Brazilian law. The sample from P3 presented low levels of dissolved oxygen and low $\mathrm{pH}$. It is important to highlight that although Resolution 357 of CONAMA does not establish limits for electrical conductivity, according to the Environmental Company of the State of São Paulo (CETESB, 2015), levels above $100 \mu \mathrm{s} / \mathrm{cm}$ are indicative of impacted environments. That is the case at P1 and P3. Thus, with respect to physical parameters, only water from P2 and P4 appears to be appropriate for human consumption.

Table 1. Physical characteristics of the surface water collected along the Extrema River.

\begin{tabular}{cccccc}
\hline Sample & $\begin{array}{c}\text { Temperature } \\
\left({ }^{\circ} \mathrm{C}\right)\end{array}$ & $\begin{array}{c}\text { Turbidity } \\
(\mathrm{NTU})\end{array}$ & $\begin{array}{c}\text { Electrical conductivity } \\
(\mu \mathrm{s} / \mathrm{cm})\end{array}$ & $\begin{array}{c}\text { Dissolved oxygen } \\
(\mathrm{mg} / \mathrm{L} \mathrm{O})\end{array}$ & $\mathrm{pH}$ \\
\hline $\mathbf{P 1}$ & 19.3 & 70.2 & 104.1 & 60.6 & 6.7 \\
$\mathbf{P 2}$ & 18.3 & 40.8 & 35.7 & 131.3 & 6.8 \\
$\mathbf{P 3}$ & 19 & 34.1 & 337.2 & $1.5^{*}$ & $5.7^{*}$ \\
$\mathbf{P 4}$ & 18.2 & 24.4 & 76.5 & 85.8 & 6.3 \\
$\begin{array}{c}\text { Levels permitted } \\
\text { by Brazilian law }\end{array}$ & - & $\leq \mathbf{1 0 0}$ & - & $\mathbf{\geq 5 . 0}$ & $\mathbf{6 . 0 - 9 . 0}$ \\
\hline
\end{tabular}

*Levels not permitted by CONAMA for Class 2 water bodies (Resolution $n^{\circ}$ 357/2005).

Water collected from the sampling points was analyzed for N, P, and trace metal contents (Table 2). Water collected at P3 presented the highest $\mathrm{N}, \mathrm{P}$, and Fe contents. The Fe and $\mathrm{Cr}$ contents were above the limits established by Brazilian law at all sampling points. Therefore, 
with respect to chemical content, water from the Extrema River is not appropriate for human consumption.

Table 2. N, P, and trace metal contents $(\mathrm{mg} / \mathrm{L})$ in the surface water collected at different locations from the Extrema River.

\begin{tabular}{cccccccc}
\hline Sample & $\begin{array}{c}\text { Ammoniacal nitrogen } \\
\left(\mathbf{N H}_{4}-\mathbf{N}\right)\end{array}$ & $\begin{array}{c}\text { Orthophosphate } \\
\left(\mathbf{P O}_{4}-\mathbf{P}\right)\end{array}$ & $\mathbf{F e}$ & $\mathbf{C r}$ & $\mathbf{P b}$ & $\mathbf{Z n}$ & $\mathbf{C u}$ \\
\hline P1 & 0.0005 & 0.0006 & $0.375^{*}$ & $0.317^{*}$ & 0.010 & $\mathrm{ND}$ & $\mathrm{ND}$ \\
P2 & 0.0035 & 0.0008 & $0.444^{*}$ & $0.345^{*}$ & 0.010 & $\mathrm{ND}$ & $\mathrm{ND}$ \\
P3 & 0.0481 & $0.0562^{*}$ & $11.046^{*}$ & $0.345^{*}$ & 0.010 & $\mathrm{ND}$ & $\mathrm{ND}$ \\
P4 & 0.0220 & 0.0142 & $2.885^{*}$ & $0.345^{*}$ & 0.010 & $\mathrm{ND}$ & $\mathrm{ND}$ \\
$\begin{array}{c}\text { Levels permitted } \\
\text { by Brazilian law }\end{array}$ & $\mathbf{3 . 7}$ & $\mathbf{0 . 0 5}$ & $\mathbf{0 . 3}$ & $\mathbf{0 . 0 5}$ & $\mathbf{0 . 0 1}$ & $\mathbf{0 . 1 8}$ & $\mathbf{0 . 0 0 9}$ \\
\hline
\end{tabular}

"Levels not permitted by CONAMA for Class 2 water bodies (Resolution $\mathrm{n}^{\circ}$ 357/2005);

ND: not detected.

\subsection{Cytogenotoxicity of water collected from the Extrema River}

Water collected from the Extrema River (P1-P4) was evaluated using the A. cepa model to verify its cyto genotoxic potential (Table 3). Water collected at P1 and P2 was found to increase A. cepa root growth, suggesting the presence of substances with mitogenic activity. In agreement with this result, the MI of P1 was higher than the MI of the NC. However, the MIs of the other sample points (P2, P3, and P4) were similar to that of the negative control. In contrast, the number of CNAs was higher in A. серa meristematic cells treated with water collected at P3 than in the negative control, indicating the genotoxic effect of the water collected from P3. The most common CNAs observed were chromosome bridge, lagging chromosome, chromosome stickiness, chromosome loss, chromosome break, C-mitosis, binucleated cell, and nuclear bud (Figure 2). Water samples collected at P2, P3, and P4 were seen to induce MN formation in A. cepa meristematic cells (Table 3 and Figure 2) when compared with the negative control, indicating its mutagenic potential.

Table 3. Cytogenotoxic evaluation of surface water collected from the Extrema River using the Allium cepa model.

\begin{tabular}{ccccc}
\hline Sample & $\begin{array}{c}\text { Toxicity } \\
\text { (root length, cm) }\end{array}$ & $\begin{array}{c}\text { Cytotoxicity } \\
(\text { MI, \%) }\end{array}$ & $\begin{array}{c}\text { Genotoxicity } \\
(\text { CNA })\end{array}$ & $\begin{array}{c}\text { Mutagenicity } \\
(\text { MN })\end{array}$ \\
\hline P1 & $5.80 \pm 0.55 \mathrm{~b}$ & $5.12 \pm 1.77 \mathrm{a}$ & $5.80 \pm 2.16 \mathrm{a}$ & $0 \mathrm{a}$ \\
$\mathbf{P 2}$ & $5.56 \pm 1.17 \mathrm{~b}$ & $3.42 \pm 1.20 \mathrm{a}$ & $7.40 \pm 1.81 \mathrm{a}$ & $1.00 \pm 0.70 \mathrm{~b}$ \\
P3 & $1.50 \pm 0.47 \mathrm{ac}$ & $4.84 \pm 0.91 \mathrm{a}$ & $13.80 \pm 5.01 \mathrm{~b}$ & $1.60 \pm 1.81 \mathrm{~b}$ \\
P4 & $3.50 \pm 1.55 \mathrm{ad}$ & $4.14 \pm 1.17 \mathrm{a}$ & $6.80 \pm 3.49 \mathrm{a}$ & $1.60 \pm 1.52 \mathrm{~b}$ \\
Negative Control & $2.85 \pm 0.36 \mathrm{a}$ & $4.44 \pm 1.80 \mathrm{a}$ & $2.00 \pm 1.41 \mathrm{a}$ & $0 \mathrm{a}$ \\
\hline
\end{tabular}

Data are presented as mean \pm standard deviation. Equal letters represent data belonging to the same population. Different letters represent statistically significant differences $(\mathrm{p}<0.05)$.

MI: mitotic index; CNA: chromosomal and nuclear aberrations; MN: micronucleus. 

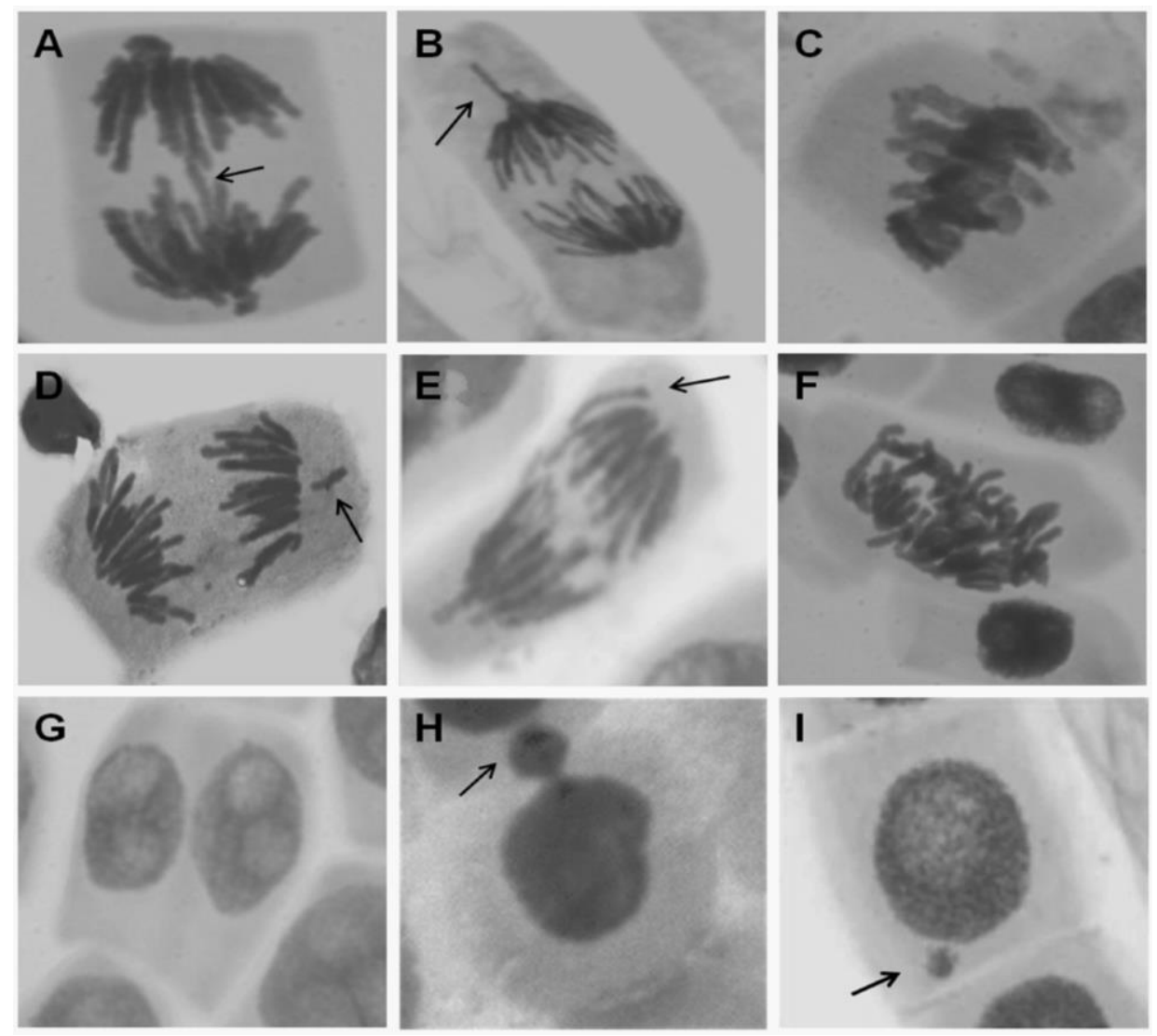

Figure 2. Most common chromosomal and nuclear aberrations (CNAs) observed in the Allium cepa meristematic cells exposed to water from the Extrema River. A: chromosome bridge; B: lagging chromosome; C: chromosome stickiness; D: chromosome break; E: chromosome loss; F: Cmitosis; G: binucleated cell; H: nuclear bud; and I: micronucleus.

\subsection{Relationship between land-use pattern, water quality and cellular alterations}

The land-use analysis data, obtained from land-use mapping and soil cover, are presented in Table 4.

Analysis of the regression coefficient showed that the A. cepa root length was directly proportional to the $\mathrm{pH}$ of the water and inversely proportional to the amount of $\mathrm{Fe}$ and ammoniacal nitrogen in the water. In agreement with the ammoniacal nitrogen relation, the root length was inversely proportional to pasture areas with a radius of $2000 \mathrm{~m}$. CNAs were positively related to Fe and to orthophosphate content. CNA showed a positive correlation with the area occupied by water with a radius of $500 \mathrm{~m}$, agricultural area with a radius of $2000 \mathrm{~m}$, and an area of exposed soil with a radius of $2000 \mathrm{~m}$. MN frequency was inversely proportional to water turbidity and did not present any relationship with land use. Also, because MI was not statistically different among the sampled collection points, the MI did not present a specific relationship with any parameter of water quality and land use investigated in this work (Table 5).

Investigations regarding the characteristics at each sample collection point along the Extrema River revealed that P1 presented a relation with urban areas in the three analyzed buffer distances (Figure 3). This was expected because the highest values of area occupied by urban class land use were observed near P1 (Table 4). This point presented the lowest Cr content, placing P1 opposite to the $\mathrm{Cr}$ vector in the canonical correspondence chart (Figure 3). By extension, P1 also presented the lowest relationship with MN, CNA, and MI (Figure 3). 
Table 4. Measurement of areas occupied by the land-use classes for landuse analysis.

\begin{tabular}{|c|c|c|c|c|c|c|c|}
\hline \multirow{2}{*}{ Sample } & \multicolumn{7}{|c|}{ Classes of land use and land cover (area values in $\mathbf{k m}^{\mathbf{2}}$ ) } \\
\hline & $\begin{array}{c}\text { Agri } \\
\mathbf{5 0 0} \mathbf{~ m}\end{array}$ & $\begin{array}{c}\text { Wat } \\
500 \mathrm{~m}\end{array}$ & $\begin{array}{c}\text { Urb } \\
\mathbf{5 0 0 ~} \mathbf{m}\end{array}$ & $\begin{array}{c}\text { Pas } \\
\mathbf{5 0 0 ~} \mathrm{m}\end{array}$ & $\begin{array}{c}\text { For } \\
\mathbf{5 0 0 ~} \mathbf{m}\end{array}$ & $\begin{array}{l}\text { Burn } \\
\mathbf{5 0 0} \mathbf{~ m}\end{array}$ & $\begin{array}{c}\text { Soil } \\
\mathbf{5 0 0 ~} \mathbf{m}\end{array}$ \\
\hline P1 & 0.02 & 0.00 & 0.22 & 0.26 & 0.11 & 0.17 & 0.00 \\
\hline $\mathrm{P} 2$ & 0.02 & 0.00 & 0.09 & 0.32 & 0.14 & 0.22 & 0.01 \\
\hline P3 & 0.08 & 0.00 & 0.00 & 0.45 & 0.08 & 0.00 & 0.17 \\
\hline P4 & 0.03 & 0.00 & 0.11 & 0.29 & 0.27 & 0.09 & 0.00 \\
\hline Sample & $\begin{array}{c}\text { Agri } \\
1000 \mathrm{~m}\end{array}$ & $\begin{array}{c}\text { Wat } \\
1000 \mathrm{~m}\end{array}$ & $\begin{array}{c}\text { Urb } \\
1000 \mathrm{~m}\end{array}$ & $\begin{array}{c}\text { Pas } \\
1000 \mathrm{~m}\end{array}$ & $\begin{array}{c}\text { For } \\
1000 \mathrm{~m}\end{array}$ & $\begin{array}{c}\text { Burn } \\
1000 \mathrm{~m}\end{array}$ & $\begin{array}{c}\text { Soil } \\
1000 \mathrm{~m}\end{array}$ \\
\hline P1 & 0.04 & 0.04 & 1.61 & 0.99 & 0.20 & 0.23 & 0.04 \\
\hline P2 & 0.10 & 0.00 & 0.87 & 1.26 & 0.38 & 0.42 & 0.12 \\
\hline P3 & 0.15 & 0.03 & 0.04 & 1.76 & 0.39 & 0.02 & 0.75 \\
\hline P4 & 0.06 & 0.00 & 0.38 & 1.27 & 0.62 & 0.81 & 0.00 \\
\hline Sample & $\begin{array}{c}\text { Agri } \\
2000 \mathrm{~m}\end{array}$ & $\begin{array}{c}\text { Wat } \\
2000 \mathrm{~m}\end{array}$ & $\begin{array}{c}\text { Urb } \\
2000 \mathrm{~m}\end{array}$ & $\begin{array}{c}\text { Pas } \\
2000 \mathrm{~m}\end{array}$ & $\begin{array}{c}\text { For } \\
2000 \mathrm{~m}\end{array}$ & $\begin{array}{c}\text { Burn } \\
2000 \mathrm{~m}\end{array}$ & $\begin{array}{c}\text { Soil } \\
2000 \mathrm{~m}\end{array}$ \\
\hline $\mathrm{P} 1$ & 0.19 & 0.04 & 7.25 & 2.63 & 1.28 & 0.94 & 0.25 \\
\hline P2 & 0.30 & 0.02 & 6.74 & 3.41 & 1.17 & 0.62 & 0.31 \\
\hline P3 & 1.01 & 0.06 & 1.25 & 6.28 & 1.40 & 0.16 & 2.41 \\
\hline P4 & 0.32 & 0.00 & 1.31 & 5.38 & 2.79 & 2.41 & 0.35 \\
\hline
\end{tabular}

Agri: Agriculture; Wat: Water; Urb: Urban area; Pas: Pasture; For: Forest; Burn: Burn scars; Soil: Exposed soil. 500 m, 1000 m, and 2000 m codes are relative to the buffer radius lengths presented in Figure 1.

Table 5. Regression coefficient $\left(\mathrm{R}^{2}\right)$ and statistical significance (p) of the relationship between parameters investigated using the Allium cepa model and those related to water quality and land use.

\begin{tabular}{cccc}
\hline Allium cepa parameters & Water- and land-use parameters & $\mathbf{R}^{\mathbf{2}}$ & $\mathbf{p}$ \\
\hline \multirow{2}{*}{ Root length } & $\mathrm{pH}$ & 0.98 & 0.01 \\
& $\mathrm{Fe}$ & -0.95 & 0.04 \\
& $\mathrm{NH}_{4}-\mathrm{N}$ & -0.99 & 0.000 \\
& Pasture in $2000 \mathrm{~m}$ & -0.97 & 0.02 \\
\hline CNA & $\mathrm{Fe}$ & 0.96 & 0.03 \\
& Orthophosphate & 0.96 & 0.03 \\
& Water in $500 \mathrm{~m}$ & 0.98 & 0.01 \\
& Agriculture in $2000 \mathrm{~m}$ & 0.99 & 0.004 \\
& Exposed soil in $2000 \mathrm{~m}$ & 0.98 & 0.01 \\
\hline $\mathrm{MN}$ & Turbidity & -0.97 & 0.02 \\
\hline $\mathrm{MI}$ & $\mathrm{ND}$ & $\mathrm{ND}$ & $\mathrm{ND}$ \\
\hline
\end{tabular}

CNA: chromosomal and nuclear aberration; MN: micronucleus; MI: mitotic index; ND: not determined. 


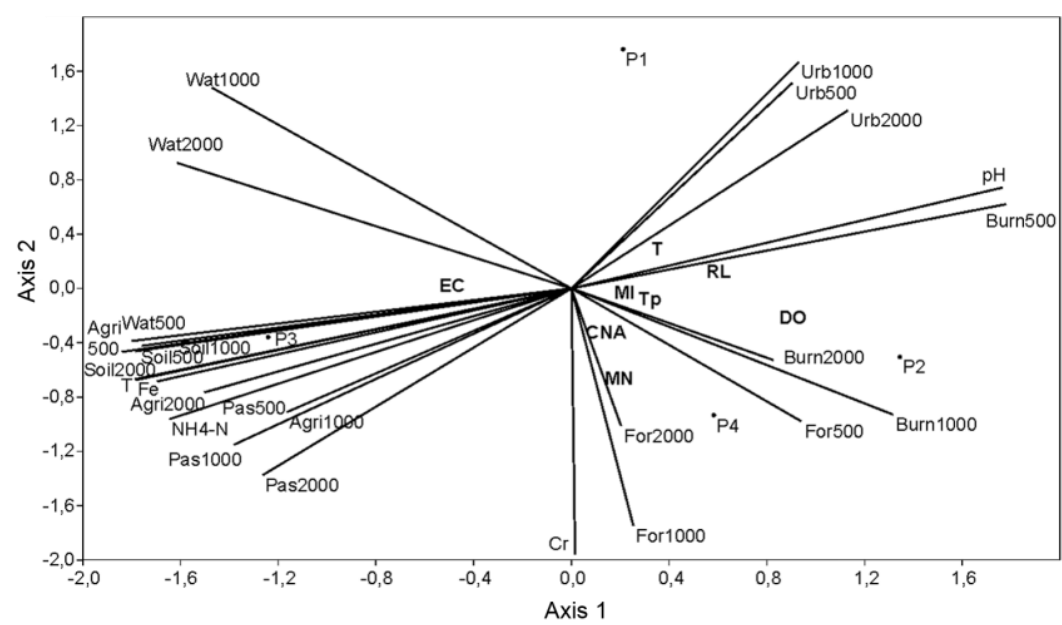

Figure 3. The relationship between water quality, soil use and toxicity parameters with the water samples collected along the Extrema River. A canonical correspondence analysis showed that the water collected along the Extrema River was, in general, more related to the landscape pattern than to water parameters (physicochemical and toxicological). In agreement, Allium cepa parameters were more related to the landscape use characteristics than to the water quality parameters per se.

P2 and P4 are interrelated and related to burn scars and forest use (Figure 3) in the different distances analyzed, because these classes of land use occupy more areas around the two points (Table 4) and present land-use patterns most related to dissolved oxygen (DO), water $\mathrm{pH}, \mathrm{Cr}$ content, and A. cepa parameters [root length (RL), CNA, MN, and MI]. Burned areas are related to P2 and P4 land-use patterns; thus, the effects observed in the water at these points are probably caused by this type of land use. P3 is the point most related to agriculture, pasture, and exposed soil classes. In agreement, $\mathrm{P} 3$ was related to $\mathrm{NH}_{4}-\mathrm{N}, \mathrm{Fe}$, orthophosphate, lower $\mathrm{pH}$, and electrical conductivity (EC).

\section{DISCUSSION}

A water quality assessment is the evaluation of the physical, chemical, and biological nature of the water. However, the majority of the studies consider only one method for monitoring water quality (Chapman, 1996). In this work, we evaluated the physical, chemical, and toxic potential of water collected from the Extrema River, a low-order stream. To complement this strategy, we also evaluated the land-use patterns in the basin and derived the relationship between land use and water quality.

Water collected at $\mathrm{P} 3$ was the most affected and presented low levels of dissolved oxygen, low $\mathrm{pH}, \mathrm{EC}$ above $100 \mu \mathrm{s} / \mathrm{cm}$, high levels of $\mathrm{P}, \mathrm{Fe}$, and $\mathrm{Cr}$, and a high number of CNAs and MN. High phosphorus content could explain the low levels of dissolved oxygen. Eutrophication management has centered on phosphorus control (Dodds et al., 2009). In this scenario, orthophosphate is important because it is the principal form of phosphate assimilated by autotrophs (Correll, 1998). The nutrient input can cause an increase in algal blooms, which consume $\mathrm{O}_{2}$ and are detrimental to water quality (Dodds et al., 2009). Phosphorus levels may increase because of fertilizer use and the inflow of municipal and industrial wastewater (Conley et al., 2009). A sewage treatment plant near P3 that disposes its effluents can be considered as the phosphorus source. Moreover, the land-use study revealed that P3 was the point most related to agriculture, pasture, and exposed soil. The increase in nutrients in the soil because of agricultural fertilization makes surface water more susceptible to the inflow of these elements 
(Permatasari et al., 2017). Soil areas exposed by erosion, through which nutrient elements are carried to lower parts of the terrain (usually where the water bodies run), also contribute to the inflow of these nutrients in surface waters (Bertol et al., 2003).

Furthermore, the higher EC observed at P3 could be explained by the chemical element input into the water at this point; these chemical elements are derived from activities in the surrounding areas, such as agricultural fertilization and wastewater disposal. Similar results have been reported by Ribeiro et al. (2014). An increase in EC with an increase in the agricultural area was observed. The concentration of ions in water increased with an increase in the proportion of agricultural land, corroborating the potential for nutrient transport from soil to water (Ribeiro et al., 2014).

The high levels of CNA and MN observed in A. cepa cells treated with water collected at $\mathrm{P} 3$ can be explained by the high content of $\mathrm{Fe}$ and $\mathrm{Cr}$ detected. Transition metal ions, including $\mathrm{Fe}$ and $\mathrm{Cr}$, can catalyze hydrogen peroxide decomposition with the generation of hydroxyl radicals $(\mathrm{HO} \bullet)$, known as Fenton and Fenton-like reactions. Therefore, in biological systems, transition metals can undergo redox cycling reactions and produce reactive oxygen species (ROS) (Chumakov et al., 2016). ROS can promote DNA breaks and mutations responsible for chromosome aberrations and micronucleus formation (Luzhna et al., 2013). Interestingly, we observed a positive relation between CNA and Fe content. The presence and bioaccumulation of trace metals in surface water and the influence of these elements on toxicogenomic damage both in A. cepa and in the fish Oreochromis niloticus were previously investigated (Matos et al., 2017).

Similar to our work, previous studies have reported that some anthropogenic activities in river basins, such as urbanization and agriculture, play an important role in water quality as sources of pollution and cause significant changes in the soil surface and the runoff of nutrients (Sliva and Williams, 2001; Buck et al., 2004; Lee et al., 2009; Huang et al., 2013). This relationship highlights the urgent necessity for preserving the Extrema River spring. Similar to P3, the water collected at P1 presented an EC above $100 \mu \mathrm{s} / \mathrm{cm}$ and levels of Fe and $\mathrm{Cr}$ above the limits established by Brazilian law (CONAMA, 2005). Although P1 is considered a river spring, it is located in an area with high urbanization and pasture use, which contributes to its impacted environment.

The results obtained for $\mathrm{P} 2$ and $\mathrm{P} 4$ are interesting because both are related to burn scars and forest use and are more related to dissolved oxygen (DO), water $\mathrm{pH}, \mathrm{Cr}$ content and A. cepa parameters [root length (RL), CNA, MN, and MI]. These results seem in contrast with what was previously observed, because forests are supposed to mitigate water quality degradation (Sliva and Williams 2001; Lee et al., 2009). However, it is important to highlight that the burned areas also had correlations with the same parameters as P2 and P4. Therefore, it is probable that the effects observed in the water at these points are caused primarily by the burns. Forest-land water cannot always be considered adequate for human consumption, as the nitrogen output is high in forested areas during storms, heavy rainfall, and burns (Tong and Chen, 2002; Smith et al., 2011). Following burns, increased erosion rates and changes in runoff generation and pollutant sources may greatly increase the flux of sediment, nutrients, and other water quality constituents, potentially contaminating water bodies. In the first year post-fire, suspended sediment, total $\mathrm{N}$, total $\mathrm{P}, \mathrm{Fe}, \mathrm{Mn}, \mathrm{As}, \mathrm{Cr}, \mathrm{Al}, \mathrm{Ba}$, and $\mathrm{Pb}$ exports commonly increase compared with unburned areas (Smith et al., 2011).

\section{CONCLUSION}

The physicochemical and genotoxic results obtained from this study showed that the surface water of the Extrema River is inappropriate for human consumption and in urgent need of preservation actions. Additionally, the A. серa assay was shown to be a useful genotoxic hazard recognition tool that should be implemented in monitoring programs. The multivariable 
analysis associated the physicochemical and cytogenotoxic parameters with the different uses of the land, demonstrating that the type of land use changed the water characteristics.

\section{ACKNOWLEDGMENTS}

The author(s) disclosed receipt of the following financial support for the research, authorship, and/or publication of this article: The author Leovigildo Aparecido Costa Santos was supported with a scholarship from Coordenação de Aperfeiçoamento de Pessoal de Nível Superior (CAPES); the authors Sara dos Santos Almeida and Patrícia Lima D'abadia were supported with a scholarship from Fundação de Amparo à Pesquisa do Estado de Goiás (FAPEG); the authors Elisa Flávia Luiz Cardoso Bailão, Samantha Salomão Caramori, and Luciane Madureira de Almeida were supported by Universidade Estadual de Goiás with a fellowship of the program PROBIP (Scientific Production Support Program). This study was financed in part by the CAPES - Finance Code 001 (Convênio n ${ }^{\circ}$ 817164/2015 CAPES/PROAP) and by FAPEG.

\section{REFERENCES}

BERTOL, I.; MELLO, E. L.; GUADAGNIN, J. C.; ZAPAROLLI, A. L. V.; CARRAFA, M. R. Nutrient losses by water erosion. Scientia Agricola, v. 60, n. 3, p. 581-586, 2003. http://dx.doi.org/10.1590/S0103-90162003000300025

BOLLANI, S.; CABO, L.; CHAGAS, C.; MORETTON, J.; WEIGANDT, C.; DE IORIO, A. F.; MAGDALENO, A. Genotoxicity of water samples from an area of the Pampean region (Argentina) impacted by agricultural and livestock activities. Environmental Science and Pollution Research, n. 26, p. 27631-27639, 2018. https://doi.org/10.1007/s11356-018-3263-9

BRION, G.; BRYE, K. R.; HAGGARD, B. E.; WEST, C.; BRAHANA, J. V. Land-use effects on water quality of a first-order stream in the Ozark Highlands, mid-southern United States. River Research and Applications, v. 27, n. 6, p. 772-790, 2011. https://doi.org/10.1002/rra.1394

BU, H.; MENG, W.; ZHANG, Y.; WAN, J. Relationships between land use patterns and water quality in the Taizi River basin, China. Ecological Indicators, v. 41, p. 187-197, 2014. https://doi.org/10.1016/j.ecolind.2014.02.003

BUCK, O.; NIYOGI, D. K.; TOWNSEND, C. R. Scale-dependence of land use effects on water quality of streams in agricultural catchments. Environmental Pollution, v. 130, n. 2, p. 287-299, 2004. https://doi.org/10.1016/j.envpol.2003.10.018

CAO, F. F.; LI, X.; WANG, D.; ZHAO, Y.; WANG, Y. Q. Effects of land use structure on water quality in Xin'anjiang River. Huan Jing Ke Xue, v. 34, n. 7, p. 2582-2587, 2013.

CETESB. Relatório de qualidade das águas superficiais. Apêndice D: Significado ambiental e sanitário das variáveis de qualidade. São Paulo, 2015.

CHAPMAN, D. V. Water quality assessments: a guide to the use of biota, sediments and water in environmental monitoring. 2nd ed. London: E \& FN Spon, 1996.

CHENG, P.; MENG, F.; WANG, Y.; ZHANG, L.; YANG, Q.; JIANG, M. The impacts of land use patterns on water quality in a trans-boundary river basin in Northeast China based on eco-functional regionalization. International Journal of Environmental Research and Public Health, v. 15, n. 9, 2018. https://doi.org/10.3390/ijerph15091872 
CHUMAKOV, A.; BATALOVA, V.; SLIZHOV, Y. Electro-Fenton-like reactions of transition metal ions with electrogenerated hydrogen peroxide. AIP Conference Proceedings, v. 1772, n. 1, p. 40004, 2016. https://doi.org/10.1063/1.4964563

CLIMATE-DATA. Dados climatológicos para Anápolis. 2020. Available at: https://pt.climate-data.org/america-do-sul/brasil/goias/anapolis-3192/. Access: 08 March 2020.

CODEGO. Acesso à informação. Anápolis, 2018.

CONAMA (Brasil). Resolução n 357 de 17 de março de 2005. Dispõe sobre a classificação dos corpos de água e diretrizes ambientais para o seu enquadramento, bem como estabelece as condições e padrões de lançamento de efluentes, e dá outras providências. Diário Oficial [da] União: seção 1, Brasília, DF, n. 053, p. 58-63, 18 mar. 2005.

CONLEY, D. J.; PAERL, H. W.; HOWARTH, R. W.; BOESCH, D. F.; SEITZINGER, S. P.; HAVENS, K. E.; LANCELOT, C.; LIKENS, G. E. Controlling eutrophication: Nitrogen

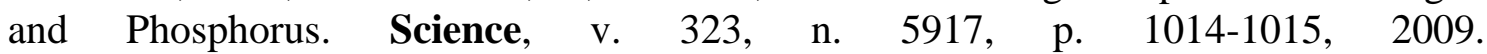
https://doi.org/10.1126/science.116775

CORRELL, D. L. The role of phosphorus in the eutrophication of receiving waters: a review. Journal of Environmental Quality, v. 27, p. 261-266, 1998.

DING, J.; JIANG, Y.; FU, L.; LIU, Q.; PENG, Q.; KANG, M. Impacts of land use on surface water quality in a subtropical river basin: a case study of the Dongjiang River Basin, Southeastern China. Water, v. 7, n. 8, 2015. http://dx.doi/10.3390/w7084427

DING, J.; JIANG, Y.; LIU, Q.; HOU, Z.; LIAO, J.; FU, L.; PENG, Q. Influences of the land use pattern on water quality in low-order streams of the Dongjiang River basin, China: A multi-scale analysis. Science of the Total Environment, v. 551-552, p. 205-216, 2016. https://doi.org/10.1016/j.scitotenv.2016.01.162

DODDS, W. K.; BOUSKA, W. W.; EITZMANN, J. L.; PILGER, T. J.; PITTS, K. L.; RILEY, A. J.; SCHLOESSER, J. T.; THORNBRUGH, D. J. Eutrophication of U.S. freshwaters: analysis of potential economic damages. Environmental Science and Technology, v. 43, n. 1, p. 12-19, 2009. https://doi.org/10.1021/es801217q

DODDS, W. K.; OAKES, R. M. Headwater influences on downstream water quality. Environmental Management, v. 41, n. 3, p. 367-377, 2008. https://doi.org/10.1007/s00267-007-9033-y

DÜSMAN, E.; LUZZA, M.; SAVEGNAGO, L.; LAUXEN, D.; VICENTINI, V. E.; TONIAL, I. B.; SAUER, T. P. Allium cepa L. as a bioindicator to measure cytotoxicity of surface water of the Quatorze River, located in Francisco Beltrão, Paraná, Brazil. Environmental Monitoring and Assessment, v. 186, n. 3, p. 1793-1800, 2014. https://doi.org/10.1007/s10661-013-3493-8

FEDEL-MIYASATO, L. E.; FORMAGIO, A. S.; AUHAREK, S. A.; KASSUYA, C. A.; NAVARRO, S. D.; CUNHA-LAURA, A. L.; MONREAL, A. C.; VIEIRA, M. C.; OLIVEIRA, R. J. Antigenotoxic and antimutagenic effects of Schinus terebinthifolius Raddi in Allium cepa and Swiss mice: a comparative study. Genetics and Molecular Research, v.13, p. 3411-3425, 2014.

FREEMAN, M. C.; PRINGLE, C. M.; JACKSON, C. R. Hydrologic connectivity and the contribution of stream headwaters to ecological integrity at regional scales. JAWRA Journal of the American Water Resources Association, v. 43, n. 1, p. 5-14, 2007. https://doi.org/10.1111/j.1752-1688.2007.00002.x 
FERREIRA, M. E.; FERREIRA, L. G.; LATRUBESSE, E. M.; MIZIARA, F. Considerations about the land use and conversion trends in the savanna environments of Central Brazil under a geomorphological perspective. Journal of Land Use Science, v. 11, p. 33-47, 2014. https://doi.org/10.1080/1747423X.2013.845613

GIRI, S.; QIU, Z. Understanding the relationship of land uses and water quality in Twenty First Century: A review. Journal of Environmental Management, v. 173, p. 41-48, 2016. https://doi.org/10.1016/j.jenvman.2016.02.029

HUANG, J.; ZHAN, J.; YAN, H.; WU, F.; DENG, X. Evaluation of the impacts of land use on water quality: a case study in the Chaohu Lake Basin. Scientific World Journal, v. 2013, n. 329187, 2013. http://dx.doi.org/10.1155/2013/329187

KANG, J. H.; LEE, S. W.; CHO, K. H.; KI, S. J.; CHA, S. M.; KIM, J. H. Linking land-use type and stream water quality using spatial data of fecal indicator bacteria and heavy metals in the Yeongsan river basin. Water Research, v. 44, n. 14, p. 4143-4157, 2010. https://doi.org/10.1016/j.watres.2010.05.009

KHAN, M. Y. A.; GANI, K. M.; CHAKRAPANI, G. J. Assessment of surface water quality and its spatial variation. A case study of Ramganga River, Ganga Basin, India. Arabian Journal of Geosciences, v. 9, n. 1, p. 28, 2016. https://doi.org/10.1007/s12517-015-2134-7

KHAN, M. Y. A.; KHAN, B.; CHAKRAPANI, G. J. Assessment of spatial variations in water quality of Garra River at Shahjahanpur, Ganga Basin, India. Arabian Journal of Geosciences, v. 9, n. 8, p. 516, 2016. https://doi.org/10.1007/s12517-016-2551-2

KHAN, M. Y. A.; GANI, K. M.; CHAKRAPANI, G. J. Spatial and temporal variations of physicochemical and heavy metal pollution in Ramganga River - a tributary of River Ganges, India. Environmental earth sciences, v. 76, n. 5, p. 231, 2017. https://doi.org/10.1007/s12665-017-6547-3

LEE, M. D.; BASTEMEIJER, T. F. Drinking water source protection: a review of environmental factors affecting community water supplies. IRC International Water and Sanitation Centre, p. 5-34, 1991.

LEE, S. W.; HWANG, S. J.; LEE, S. B.; HWANG, H. S.; SUNG, H. C. Landscape ecological approach to the relationships of land use patterns in watersheds to water quality characteristics. Landscape and Urban Planning, v. 92, n. 2, p. 80-89, 2009. https://doi.org/10.1016/j.landurbplan.2009.02.008

LEME, D. M.; MARIN-MORALES, M. A. Allium cepa test in environmental monitoring: a review on its application. Mutation Research, v. 682, n. 1, p. 71-81, 2009. https://doi.org/10.1016/j.mrrev.2009.06.002

LI, S.; GU, S.; TAN, X.; ZHANG, Q. Water quality in the upper Han River basin, China: The impacts of land use/land cover in riparian buffer zone. Journal of Hazardous Materials, v. 165, n. 1, p. 317-324, 2009. https://doi.org/10.1016/j.jhazmat.2008.09.123

LUZHNA, L.; KATHIRIA, P.; KOVALCHUK, O. Micronuclei in genotoxicity assessment: from genetics to epigenetics and beyond. Frontiers in Genetics, v. 4, n. 131, 2013. https://doi.org/10.3389/fgene.2013.00131

MATOS, L. A.; CUNHA, A. C. S.; SOUSA, A. A.; MARANHÃO, J. P. R.; SANTOS, N. R. S.; GONCALVES, M. M. C. The influence of heavy metals on toxicogenetic damage in a Brazilian tropical river. Chemosphere, v. 185, p. 852-859, 2017. http://dx.doi.org/10.1016/j.chemosphere.2017.07.103 
MURPHY, J.; RILEY, J. P. A modified single solution method for the determination of phosphate in natural waters. Analytica Chimica Acta, v. 27, p. 31-36, 1962. https://doi.org/10.1016/S0003-2670(00)88444-5

NORTON, M. M.; FISHER, T. R. The effects of forest on stream water quality in two coastal plain watersheds of the Chesapeake Bay. Ecological Engineering, v. 14, n. 4, p. 337362, 2000. https://doi.org/10.1016/S0925-8574(99)00060-9

OHE, T.; WATANABE, T.; WAKABAYASHI, K. Mutagens in surface waters: a review. Mutation Research/Reviews in Mutation Research, v. 567, n. 2, p. 109-149, 2004. https://doi.org/10.1016/j.mrrev.2004.08.003

PERMATASARI, P. A.; SETIAWAN, Y.; KHAIRIAH, R. N.; EFFENDI, H. The effect of land use change on water quality: a case study in Ciliwung Watershed. IOP Conference Series: Earth and Environmental Science, v. 54, n. 1, p. 012026, 2017. http://dx.doi.org/10.1088/1755-1315/54/1/012026

RANK, J.; NIELSEN, M. H. Evaluation of the Allium anaphase-telophase test in relation to genotoxicity screening of industrial wastewater. Mutation Research, v.312, n.1, v.1724, 1994. https://doi.org/10.1016/0165-1161(94)90004-3

RIBEIRO, K. H.; FAVARETTO, N.; DIECKOW, J.; SOUZA, L. C. P.; MINELLA, J. P. G.; ALMEIDA, L. Quality of surface water related to land use: a case study in a catchment with small farms and intensive vegetable crop production in southern Brazil. Revista Brasileira de Ciência do Solo, v. 38, n. 2, p. 656-668, 2014. https://dx.doi.org/10.1590/S0100-06832014000200030

SANTOS, L. A. C.; BATISTA, A. C.; NEVES, C. O. M.; CARVALHO, E. V.; SANTOS, M. M.; GIONGO, M. Análise multitemporal do uso e cobertura da terra em nove municípios do Sul do Tocantins, utilizando imagens Landsat. Revista Agroambiente, v. 11, n. 2, p. 111-118, 2017. http://dx.doi.org/10.18227/1982-8470ragro.v11i2.3915

SANTOS, L. A. C.; LIMA, P. E. M. Comparação entre diferentes algoritmos de classificação supervisionada no mapeamento temático de uma bacia hidrográfica. Revista Tree $\begin{array}{lllllll}\text { dimensional, } & \text { v. } \quad 3, & \text { n. } & 5, & \text { p. } & 27-41, & \end{array}$ http://dx.doi.org/10.18677/TreeDimensional2018A3

SETH, C. S.; MISRA, V.; CHAUHAN, L. K.; SINGH, R. R. Genotoxicity of cadmium on root meristem cells of Allium cepa: cytogenetic and Comet assay approach. Ecotoxicology $\begin{array}{lllllll}\text { and Environmental Safety, v. 71, n. 3, p. 711-716, } 2008 . & \text {. }\end{array}$ https://dx.doi.org/10.1016/j.ecoenv.2008.02.003

SILVA, J. S.; HECK, M. C.; BUZO, M. G.; ALMEIDA, I. V.; VICENTINI, V. E. P. Evaluation of textile laundry effluents and their cytotoxic effects on Allium cepa. Environmental Science and Pollution Research, v. 25, n. 28, p. 27890-27898, 2018. https://doi.org/10.1007/s11356-018-2813-5

SLIVA, L.; WILLIAMS, D. D. Buffer Zone versus Whole Catchment Approaches to Studying Land Use Impact on River Water Quality. Water Research, v. 35, n. 14, p. 3462-3472, 2001. https://doi.org/10.1016/S0043-1354(01)00062-8

SMITH, H. G.; SHERIDAN, G. J.; LANE, P. N. J.; NYMAN, P.; HAYDON, S. Wildfire effects on water quality in forest catchments: a review with implications for water supply. $\begin{array}{llllllll}\text { Journal of Hydrology, } & \text { v. 396, } & \text { n. } 1, \quad \text { p. 170-192, }\end{array}$ https://doi.org/10.1016/j.jhydrol.2010.10.043 
SOLÓRZANO, L. Determination of ammonia in natural waters by the phenolhypochlorite method. Limnology and Oceanography, v. 14, v. 5, p. 799-801, 1969. https://doi.org/10.4319/lo.1969.14.5.0799

SOUSA, J. M. C.; PERON, A. P.; SOUSA, L. S.; HOLANDA, M. M.; LIMA, A. M. V.; OLIVEIRA, V. A.; SILVA, F. C. C.; LIMA, L. H. G. M.; MATOS, L. A.; DANTAS, S. M. M. M.; AGUIAR, R. P. S.; ISLAM, M. T.; MELO-CAVALCANTE, A. A. C.; BONECKER, C. C.; JÚLIO-JÚNIOR, H. F. Cytotoxicity and genotoxicity of Guaribas river water (Piauí, Brazil), influenced by anthropogenic action. Environmental and Monitoring Assessment, v. 189, n. 6, p. 301, 2017. https://doi.org/10.1007/s10661-017$6015-2$

SU, Z. H.; LIN, C.; MA, R. H.; LUO, J. H.; LIANG, Q. O. Effect of land use change on lake water quality in different buffer zones. Applied Ecology and Environmental Research, v. 13, n. 3, 2015. http://dx.doi.org/10.15666/aeer/1303_639653

TEIXEIRA, Z.; TEIXEIRA, H.; MARQUES, J. C. Systematic processes of land use/land cover change to identify relevant driving forces: Implications on water quality. Science of The

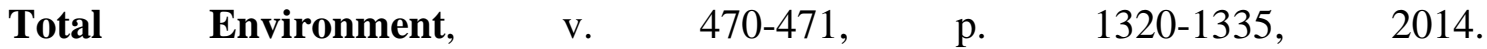
https://doi.org/10.1016/j.scitotenv.2013.10.098

TONG, S. T. Y.; CHEN, W. Modeling the relationship between land use and surface water quality. Journal of Environmental Management, v. 66, n. 4, p. 377-393, 2002. https://doi.org/10.1006/jema.2002.0593

ULLAH, K. A.; JIANG, J.; WANG, P. Land use impacts on surface water quality by statistical approaches. Global Journal of Environmental Science and Management, v. 4, n. 2, p. 231-250, 2018. http://doi.org/10.22034/gjesm.2018.04.02.010

WOLI, K. P.; NAGUMO, T.; KURAMOCHI, K.; HATANO, R. Evaluating river water quality through land use analysis and $\mathrm{N}$ budget approaches in livestock farming areas. Science of The Total Environment, v. 329, n. 1, p. 61-74, 2004. https://doi.org/10.1016/j.scitotenv.2004.03.006

XIAO, R.; WANG, G.; ZHANG, Q.; ZHANG, Z. Multi-scale analysis of relationship between landscape pattern and urban river water quality in different seasons. Scientific Reports, v. 6 , n. 25250, 2016. http://doi.org/10.1038/srep25250 